EESTI NSV TEADUSTE AKADEEMIA TOIMETISED. 29. KOIDE GEOLOOGIA. 1980, NR. 2

ИЗВЕСТИЯ АКАДЕМИИ НАУК ЭСТОНСКОИ ССР. ТОМ 29 ГЕОЛОГИЯ. 1980, № 2

\title{
К СТРАТИГРАФИЧЕСКОЙ НОМЕНКЛАТУРЕ ВЕНДСКИХ ОТЛОЖЕНИЙ ЭСТОНИИ
}

На Прибалтийском межведомственном стратиграфическом совещании (Вильнюс, май 1976 г.) рассматривалась и стратиграфическая схема вендских отложений Прибалтики, которая в настоящее время утверждена Межведомственным стратиграфическим комитетом СССР (МСК) в качестве основы при проведении разного вида геологических работ (Решения..., 1978). В корреляционной части этой схемы из-за разнофациальности и слабой палеонтологической характеристики вендских отложений региона основной единицей их расчленения принята свита. На территории Әстонии, где вендские отложения представлены явно бассейновыми отложениями и где сеть буровых скважин достаточно густая, геологическая практика показала целесообразность выделения местных подразделений также более низкого ранга - пачек. Большинство пачек выделено в процессе крупно- или среднемасштабного геологического картирования в $1960-1967$ гг. и имеют четкую литологическую характеристику, обеспечивающую их однозначное картирование. Некоторым из них в рукописных работах даны и географические названия, которые неоднократно использовались в геологических отчетах. Однако номенклатура вендских подразделений в целом нигде не публиковалась, что затрудняло ее всеобщее применение.

Ниже приводится краткий обзор выделения местных стратиграфических подразделений и излагается упорядоченная номенклатура их до уровня пачек, сохраняя при этом основной скелет схемы, принятой на Вильнюсском совещании.

Қак известно, вендские отложения на территории Эстонии представлены лишь поздневендскими образованиями - отложениями верхневалдайского цикла седиментации (Менс, Пиррус, 1974). Распространены они только в восточных и центральных районах республики, входящих в состав Восточно-Прибалтийского структурно-фациального района вендского времени (Брангулис и др., 1974). Вендские отложения отчетливо расчленяются на три свиты (гдовская, котлинская и воронковская), а последние в свою очередь на 8 пачек (см. таблицу).

Термин гдов в геологическую литературу введен Б. П. Асаткиным (1937), который под этим названием выделял толщу песчаников, залегающую на северо-западе платформы между ляминаритовыми глинами и породами кристаллического фу̃ндамента (без указания для них типового разреза). Решением МСK от 1962 г. в качестве стратотипа гдовского горизонта принят разрез Невельской опорной скважины в интервале $790-910$ м, охватывающем отложения нижнего цикла валдайского осадконакопления (Решения..., 1965). При таком подходе к расчленению валдайской серии тдовские отложения Восточной При-

1 ENSV TA Toimetised. G 21980 
балтики, западных районов Ленинградской и Псковской областей, в том числе и Гдовского района, остаются вне объема гдовского горизонта, поскольку, как показали дальнейшие исследования, нижневалдайские отложения в названных районах не развиты. $\mathrm{K}$ настоящему времени в стратиграфической схеме верхнего докембрия Русской платформы это недоразумение устранено, однако гдовские отложения в этой схеме не составляют самостоятельного стратиграфического подразделения, а выделены лишь как слои в составе котлинской свиты (Объяснительная записка..., 1978). На Прибалтийском региональном стратиграфическом совещании в 1976 г., на основании своеобразия состава и строения, а также генезиса, гдовские слои возведены в ранг свиты (Решения..., 1978). По литологическим особенностям гдовская свита отчетливо расчленяется на три пачки.

Пачку неотсортированных глинисто-гравийных пород (микстолитов), залегающую в виде линз в низах вендского разреза Эстонии, в 1965 г. Э. Эрисалу предложил назвать оруской (по скв. Ору-315, интервал $217,2-217,8$ м, керн скважины не сохранился). В настоящее время пачка может быть охарактеризована разрезом скв. Мерикюла Ф-169 (интервал 205,3-206,0 м), являющимся типовым для многих подразделений венда Эстонии (керн хранится в Управлении геологии СМ ЭССР). Более полный разрез оруской пачки имеется по скв. Пуйсма Ф-191 на глубине 202,2-209,0 м (керн хранится в Институте геологии АН ЭССР).

Залегающая выше основная часть гдовской свиты - пачка полиминеральных разнозернистых песчаников с редкими прослоями глинисто-алевритовых пород - географического названия до сих пор не имела и для нее предлагается название молдоваская по дер. Молдова (Кохтла-Ярвеский район), в черте которой в 1973 г. пробурена скв. Aa Ф-165. Интервал 183,0-215,5 м этой скважины является типовым для данной пачки (керн хранится в Институте геологии АН ЭССР).

Верхняя часть гдовской свиты - пачка переслаивания пестроокрашенных полиминеральных алевролитов и глин с волнисто-слоистой текстурой - в 1963 г., когда эта часть разреза рассматривалась еще в составе котлинской свиты, была названа А. Мардла нижнеуускюлаской пачкой по дер. Уускюла, расположенной недалеко от г. Нарвы. Начиная с 1965 г., когда в процессе среднемасштабного геологического картирования была уточнена граница между гдовской и котлинской свитами, название уускюлаская стали применять для обозначения этой пачки. Рассматриваемая пачка характеризуется разрезом скв. Мерикюла Ф-169 на глубине $150,0-194,3$ м.

Название котлин для обозначения толщи ляминаритовых глин предложено Б. С. Соколовым в 1958 г. (Соколов, 1958; Мянниль, 1958). В Эстонии в состав котлинской свиты включена вся сероцветная часть вендского разреза, содержащая алевритовые глины с ленточной текстурой, с конкрециями сидерита и пленками органического вещества по плоскостям наслоения. Включая на многих уровнях т. н. котлинский комплекс водорослей и акритарх (Волкова, 1973), данная свита дала палеонтологическое содержание для одноименного горизонта, выделенного ранее по общему строению разреза (Решения..., 1965). В районах, располагающихся к востоку от Прибалтики, сероцветные глинистые отложения котлинской свиты охватывают практически весь объем верхневалдайской части разреза (= котлинского горизонта). В краевой зоне валдайского осадконакопления, в частности в пределах Эстонии, мощность котлинской свиты существенно сокращается и разрез верхневалдайских отложений в целом построен сложнее, ввиду чего объем 
котлинского горизонта здесь значительно больше, чем объем одноименной свиты (Решения..., 1978; Объяснительная записка..., 1978).

По соотношениям типов пород и их текстурным особенностям в разрезе котлинской свиты на территории Эстонии обособляются три пачки.

Нижнюю часть свиты, сложенную преимущественно массивными сероцветными алевролитами и глинами, предлагается называть яамаской пачкой по скв. Яама, где эти отложения хорошо изучены (предложенное в 1965 г. Э. Эрисалу название вийвиконнаское за этой пачкой не закрепилось, т. к. не было опубликовано и сейчас оно используется для обозначения местного стратона ордовика). Яамаская пачка характеризуется разрезом скв. Мерикюла Ф-169 в интервале $143,6-150,0$ м.

Вышележащая, наиболее типичная часть котлинской свиты - пачка сероцветных тонкослоистых алевритовых глин - была названа в 1963 г. А. Мардла мерикюлаской по дер. Мерикюла (Кохтла-Ярвеский район). Типовым для этой пачки является разрез скв. Мерикюла Ф-169 в интервале $114,5-143,6 \mu$.

Верхняя часть котлинской свиты - маломощная пачка переслаивания сероцветных тонкослоистых и массивных алевритовых глин с прослоями алевролитов, несущая признаки регрессии, - выделена как самостоятельное подразделение в строении вендского разреза Эстонии недавно, она развита только на самом краю северо-восточной части республики (Менс, Пиррус, 1979). Для этой пачки предлагается название лаагнаская по дер. Лаагна (Кохтла-Ярвеский район) с типовым разрезом скв. Мерикюла $Ф-169$ в интервале 109,0-114,5 м.

Верхняя часть валдайского разреза, вендский возраст которой был доказан в 1967 г. (Kajak и др., 1967), рассматривалась первоначально как регрессивная часть котлинской свиты (Мардла и др., 1968; Кала и др., 1970). В виде самостоятельного подразделения, а именно как сиргалаский горизонт, эта часть разреза была выделена в 1967 г. в рукописном отчете Э. Эрисалу (без указания для него типового разреза). Дальнейшее исследование верхов валдайского разреза, в частности в долинах рек Воронка и Систа Ленинградской области, где соответствующие слои и характер их нижней и верхней границ могут быть изучены в ряде естественных обнажений, показало их стратиграфическую самостоятельность для всей северо-западной части ВосточноЕвропейской платформы. Исходя из этого, авторами настоящего сообщения было предложено выделить верхнюю часть валдайского разреза как воронковскую свиту (Менс, Пиррус, 1971). Воронковская свита сложена двумя пачками.

Нижняя пачка - переслаивание пестроокрашенных алевролитов и глин с тонкослоистой текстурой - была названа А. Мардла в 1963 г. верхнеуускюлаской. В 1965 г., когда была установлена принадлежность нижнеуускюлаской пачки к гдовской свите, Э. Эрисалу предложил назвать ее сиргалаской по пос. Сиргала (Кохтла-Ярвеский район), вблизи которого пробурена типовая для нее скв. Мустайыэ-311. Керн скв. Мустайыэ не сохранился, но сиргалаская пачка обнажается на p. Воронка в Ленинградской области и вскрыта также разрезом скв. Мерикюла Ф-169 в интервале $100,5-109,0$ м.

Верхняя пачка, сложенная светлыми слабосцементированными кварцевыми песчаниками и крупнозернистыми алевролитами с единичными прослоями разноокрашенных глинистых пород, обнажается в нескольких местах на р. Систа и р. Воронка в Ленинградской области, которые могут служить опорными разрезами пачки. Однако, поскольку стратиграфическая схема венда до уровня пачки для данной террито- 
Стратиграфическая схема вендских отложений Эстонии

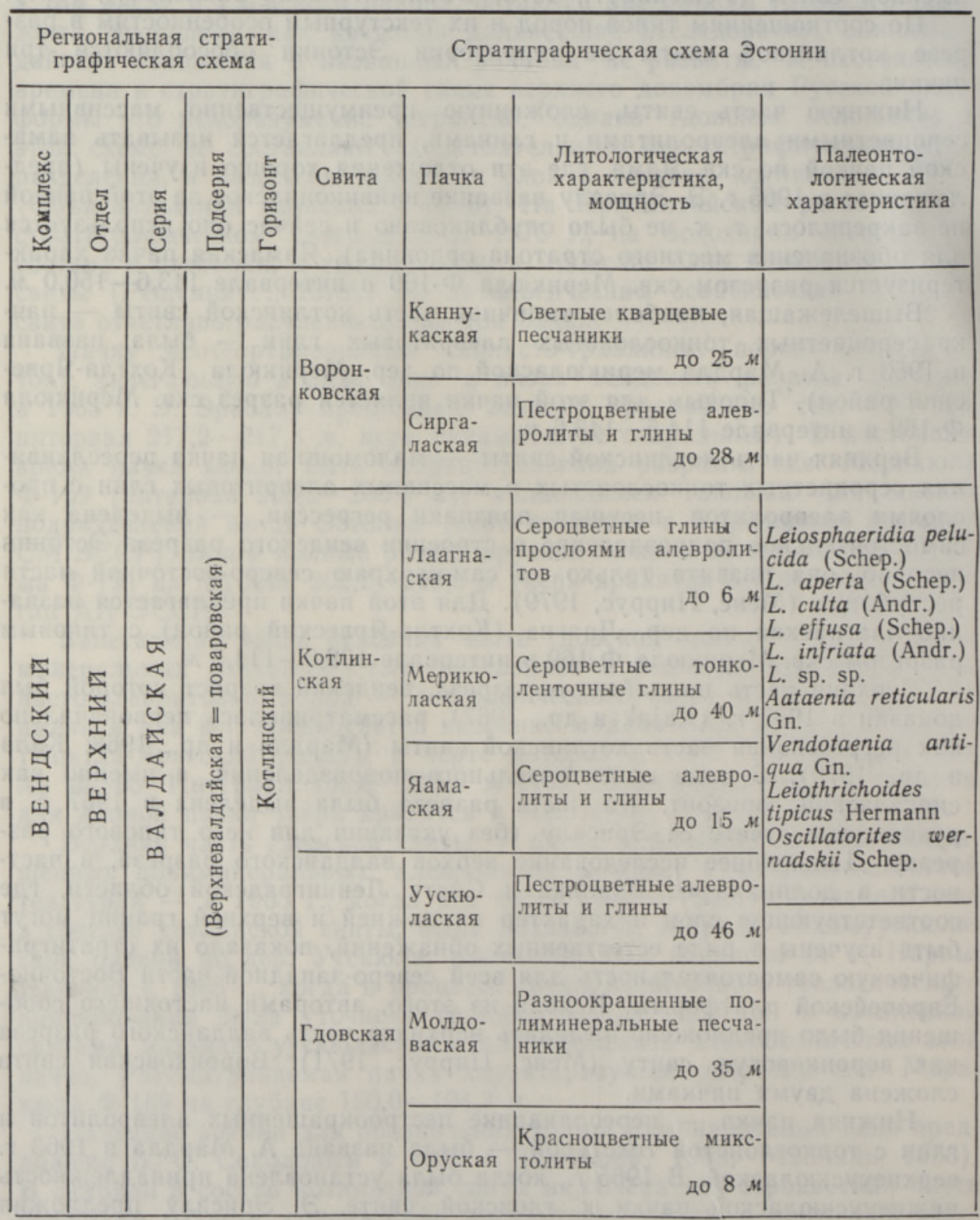

рии не разработана, Эстонская подкомиссия Прибалтийской региональной межведомственной стратиграфической комиссии рекомендовала назвать рассматриваемую часть разреза каннукаской пачкой (по дер. Каннука, Северо-Восточная Эстония). Вблизи дер. Каннука в скв. Синимяэ-314 слабосцементированные породы этой части разреза впервые были получены в виде полноценного керна, что и позволило детально их исследовать. Керн скв. Синимяэ-314 не сохранился, но каннукаская пачка в настоящее время может быть охарактеризована и разрезом скв. Мерикюла $\Phi-169$ в интервале $90,0-100,5$ м. 
Стратиграфическая схема (и номенклатура) валдайских отложений Эстонии на уровне пачек с указанием отношения к региональной схеме Прибалтики приводится в таблице. Схема эта, на наш взгляд, обеспечивает выполнение требований крупномасштабной геологической съемки и является выдержанной по принципу построения: свиты соответствуют определенным ясно выраженным этапам развития данной территории в поздневендское время, а пачки - главенствующим фациальным обстановкам осадконакопления в рамках этих этапов.

\section{Л И Т Е Р А Т Р Р А}

А с а т к и н Б. П. Докембрийские образования, кембрийские и нижнесилурийские отложения Ленинградской области. - Тр. Ленингр. геол. треста, 1937, 15, 5-8.

Брангулис А., Кала Э., Мардла А., Менс К., Пиррус Э., Сака лаускас В., Фридрихсоне А., Янкаускас Т. Схема структурнофациального районирования территории Прибалтики в венде и кембрия. Изв. АН ЭССР. Хим. Геол., 1974, 23, 218-225.

Волкова Н. А. Акритархи и корреляция венда и кембрия западной части Русской платформы. - Сов. геол., 1973, 4, 48-62.

Кала Э., М ардла А., К аяк К. Литолого-фациальная характеристика отложений вендского комплекса и балтийского яруса Эстонии. - Тез. докл. VII научной конференции геологов Прнбалтики и Белоруссии. Таллин, 1970, $65-68$.

Мардла А. К., Менс К. А., Кала Э. А., Каяк К. Ф., Эрисалу Э. К. $\mathrm{K}$ стратиграфии кембрийских отложений Эстонии. - В кн.: Стратиграфия нижнего палеозоя Прибалтики и корреляция с другими регионами. Вильнюс, $1968,22-32$.

Менс К. А., Пиррус Э. А. О стратиграфии пограничных слоев венда и кембрия на Северо-Западе Русской платформы. - Изв. АН СССР, сер. геол., $1971,11,93-103$.

Менс К. А., Пиррус Э. А. Вендские отложения Прибалтики и литогенетические особенности их формирования. - Тез. докл. совещания по верхнему докембрию (рифею) Русской платформы. Москва, 1974, 84-88.

Мен с К. А.. Пи р рус Э. А. Южный склон Балтийского щита. - В кн.: Стратиграфия верхнедокембрийских и кембрийских отложений запада ВосточноЕвропейской платформы, М., 1979, 7 -41.

М яннни ль P. M. K номенклатуре кембрийских отложений Прибалтики. - Изв. АН ЭССР, сер. техн. и физ.-мат. наук, 1958, VII, 350-352.

Объяснительная записка к схеме стратиграфии верхнего докембрия Русской платформы. Киев, 1978.

Решения Межведомственного совешания по разработке унифищированных стратиграфических схем верхнего докембрия и палеозоя Русской платформы, $1962 \mathrm{r}$. Л., 1965.

Решения Межведомственного регионального стратиграфического совещания по разработке унифицированных стратиграфических схем Прибалтики, 1976 г. Л., 1978.

Соколов Б. С. Проблема нижней границы палеозоя и древнейшие отложения досинийских платформ Евразин. - Тр. ВНИГРИ, Нов. сер., 126, Геол. сб., $1958,3,5-67$.

Kajak, K., Ka 1 a, E., Mard 1 a, A. Vendi ja kambriumi piirikihtidest Eestis. „...... VIII Eesti loodusuurijate päeva ettekannete teesid. Tartu, 1967.

\section{Ннститут геологии \\ Академии наук Эстонской ССР}

Поступила в редакцию

$1 / \mathrm{XI} 1979$ 
Kaisa MENS, E. PIRRUS

\section{EESTI VENDI KIHTIDE STRATIGRAAFILINE NOMENKLATUUR}

Artiklis on esitatud Eesti vendi setete stratigraafilise liigestuse skeem kihistike tasemel. Valdai seeria kolme kihistu piires on eristatud 8 kihistikku, mis on hästi kaardistatavad ja seetōttu leidnud juba kasutamist geoloogia praktikas. On antud nende lühike litoloogiline iseloomustus ja asend regionaalses stratigraafilises skeemis.

Kaisa MENS, E. PIRRUS

\section{ON STRATIGRAPHICAL NOMENCLATURE OF VENDIAN BEDS OF ESTONIA}

For the first time a full account of formations and members of Vendian rocks of Estonia is given, using geographical names. In most cases the units have already been distinguished by earlier authors. Some of the members have not been named, and some names of members have not been published until now.

The whole sequence is subdivided into 3 formations (Gdov, Kotlin and Voronka) and 8 members (Oru, Moldova, Uusküla, Jaama, Meriküla, Laagna, Sirgala and Kannuka). Some of the latter names are new (Moldova, Jaama, Laagna, Kannuka).

The characteristic of each rock unit is given as well as their correlation with those of the East Baltic regional stratigraphic scale (see Table). 